\title{
Digital Transparency and Performance Evaluation in Public Administration
}

\author{
Hana MOHELSKÁ, Marcela SOKOLOVÁ \\ University of Hradec Králové, Hradec Králové, Czech Republic \\ \{hana.mohelska, marcela.sokolova\}@uhk.cz
}

\begin{abstract}
Social media has opened up new opportunities for public involvement in public administration. Unlike other EU countries, the Czech Republic still faces the effects of the failure to complete the 1999 public administration reform concept. The above-mentioned public administration reform was based on: 1. reform of territorial public administration; 2. reform of the central state administration; 3. modernising and improving the efficiency of public administration. The implementation of the first and partly the second point created a system for public administration in the Czech Republic, based on a combined model of state administration performance. The combined model is characterised by the transfer of a part of the state's power to a lower level, closer to the citizens, for example through local authorities. The efficiency of Czech public administration in many areas lags behind the public administration performance in other EU member states. The aim of this paper is to examine the possibilities of measuring effectiveness in public administration and to discuss its advantages and limitations. The paper also seeks the answer to the following research question: Q1. Is digital transparency an important part of the evaluation of public administration performance? Our paper shows that the variables analysed are positively associated with digital transparency.
\end{abstract}

Keywords: Digital transparency, E-government, Internet Disclosure, Local Government.

\section{$1 \quad$ Introduction}

There are a number of approaches with regard to the conceptualisation of transparency. Some definitions are descriptive and others are of a more standard nature. A common denominator of some of those definitions is a belief in information as an essential condition of transparency. In a modern society, interlinked concepts related to transparency and governance have been defined: public-sector transparency, government transparency or organisational transparency. [10] Here, transparency is therefore considered as an essential part of rationality, progress and good governance and also "as a conduct of public affairs in the open or otherwise subject to public scrutiny". Birkinshaw [3] and Piotrowski \& Van Ryzin [14] stress the role of transparency. Prat [15] stresses the control aspects of transparency in organisations using the principal - agent model. In this case, transparency is an instrument in the 
hands of a principal where it's used to ensure that the agent is acting in line with principal through the delegation of power. Within the specified model transparency is an instrument in the hands of the principal, who can use it to ensure that the agent acting on the principal's behalf via the delegation of the power - doesn't promote their own interests instead of those belonging to the principal. When information asymmetry is to the agent's advantage, it's possible for it to lead to governance abuse and failures. Such problems are considered to be remedied by transparency. [5] Some family resemblance concepts are also related to transparency - such as openness, insight or clarity. [13] However, links between transparency, openness and information are sometimes a little vague and unclear. One way of describing the relations is provided by Christensen and Cornelissen [6], when he states that organisational openness may be a precondition for transparency, and information accessibility is seen as a precondition for openness and transparency. $[6,10]$

Several moderating effects such as administrative culture, accounting regime, measure impacts used on determining variables and the level of government have been considered and analysed for their influence on the level of correlation between the determinants as well as the disclosure of public financial information in both information disclosure modes. [1]

It's certainly evident that as the institutional framework is developed and the government transparency mechanisms and tools were strengthened, the perception of corruption became slightly less widespread. Prior research has shown that information transparency within governments depends on institutional and environmental factors. In spite of this, previous studies show heterogeneity in the results and academic researchers can't make any consistent conclusions. It makes it difficult to know the behaviour of governments regarding their information policies. [9]

\section{Theoretical Foundations of the Research}

The Czech public administration doesn't currently have a conceptual document that would set the direction for its development for the next period (after the implementation of the Smart Administration Strategy in 2015). As a reaction to the present situation, the Strategic Framework for Public Administration Development in the Czech Republic for the period 2014-2020 (hereinafter referred to as the Strategic Framework or SF) has also been developed. The purpose of this document is, in particular: to provide the continuity and implementation of other necessary steps in the public administration development area, to set further direction of the development and investment in selected areas of public administration in 2014-2020 programming period, to secure the fulfilment of the preconditions set by the European Commission as the prerequisities for making the European Structural and Investment Funds (ESIF) available to be drawn. [7]

The question of public administration development must also be perceived in the context of the development of thinking of public administration on an international level. The New Public Management concept, which dominated the professional debate at the turn of the century, is under increasing criticism, the OECD: Public 
Governance and Territorial Development Public Management Committee. [12] However, at the same time, there isn't a strong consensus on the further development and the current period can be characterised as a period of a search for new ways. The Strategic Framework for Public Administration Development in the Czech Republic for the period of 2014-2020 [11] was developed with the knowledge of this development in the global context and during its development into implementation documents, the latest international experience and the applicability of the latest ideas in public administration will be considered. $[4,16]$

\subsection{Definition of the concept of public administration}

Public administration (PA) can generally be defined as the management of public affairs carried out by PA entities or through their bodies with citizens' active participation and for their benefit. [8] Despite the PA, public tasks and PA are assured and the PA creates the prerequisites for their implementation and implements them at the same time.

\subsection{E Principles (Economy, Efficiency, Effectiveness)}

Economy - the use of public funds where the objectives and tasks are achieved with the least possible use of resources. A condition for minimising the resources used is that these objectives and tasks are met provided the quality is maintained. The indicator of economy is to minimise the cost of inputs and providing the objective is met. Achieving the set goal and therefore maintaining the appropriate quality is crucial for the economy criterion, as this is often neglected. In the event that the corresponding quality isn't met, there is an economically ineffective use of resources as the target parameters are not met.

Efficiency - productivity, or cost effectiveness. Productivity means the use of public resources to achieve the highest possible scale, the quality and benefit of performed tasks compared to the volume of resources spent on their performance (i.e. the most productive one is the one with the largest outputs achieved - the essence of benchmarking). Cost-effectiveness means cost for a neutral unit of output (e.g. cost per one citizen who is provided with services, etc.). The most cost-effective unit is the unit that achieves the lowest cost of a neutral unit of output (provided of the preservation of the given quality).

Effectiveness - effectiveness is such use of public funds to ensure an optimum level of achievement of the objectives set in the fulfilment of the assigned tasks. This is the highest type of performance criterion, both in terms of economy as well as efficiency and it examines the economic rationality of the resources used. The most common effectiveness indicator is the percentage fulfilment of the set objectives - comparison of the objectives set with the achieved results. In PA, this criterion is perceived as the most problematic, since the objectives are often not defined at all or only ambiguously or not measurable, they're not regularly evaluated, no rewards or sanctions are associated with their fulfilment or non-fulfilment. 


\section{$3 \quad$ Methodology and Data}

The paper used a method of describing the current state of public administration performance evaluation with a focus on digital transparency according to the List of Data Sets published as open data under Government Regulation No. 425/2016. [11] Furthermore, the method of comparison of the results obtained in order to answer the research question asking whether:

Q1 Is digital transparency an important part of the evaluation of public administration performance? In the course of the study, domestic and foreign specialised literary sources were used, including a reflection on the Strategic Framework for Public Administration Development in the Czech Republic for the Period $2014-2020$.

The measurement is built on two key indicators Open Data Readiness and Portal Maturity, thereby covering the national activities development levels that promote Open Data and also the national portals development levels. This data explores the Open Data Maturity level in the EU28 as well as Norway, Switzerland and Liechtenstein - referred to as EU28+. There was a $28.6 \%$ increase in 2016 in comparison to 2015, whereby the EU28+ countries completed over $55 \%$ of their Open Data journey which showed that by 2016, the majority of EU28+ countries had developed a basic approach to address Open Data successfully. The Portal Maturity level showed an increase of 22.6 percentage points from $41.7 \%$ to $64.3 \%$, this is thanks to the development of more advanced features on country data portals. The overall Open Data Maturity groups countries into different clusters: Beginners, Followers, Fast Trackers and Trend Setters. [7]

The first key indicator, Open Data Readiness, assesses to what extent countries have an Open Data policy in place, licencing standards and also the extent of national coordination with regard to the guidelines and setting common approaches. The transposition of the PSI Directive revision is also taken into account. As well as the presence of an Open Data policy, there is also an assessment of the use made from the Open Data available and the estimated political, social and economic impact of Open Data.

The second key indicator, Portal Maturity, explores the portal's usability with regard to the availability of functionalities, the overall data re-usability such as machine readability and accessibility of data sets, for example, as well as the spread of data across domains. The two key indicators as well as the sub-indicators can be seen in the following table: 
Table 1. Open Data Maturity indicators. [7]

\begin{tabular}{l|l|l|l|l|l|l|l}
\hline \multicolumn{9}{c}{ Open Data Maturity Assessment } \\
\hline \multicolumn{3}{c}{ Open Data Readiness } & \multicolumn{3}{c}{ Portal maturity } \\
\hline $\begin{array}{l}\text { Presence } \\
\text { of Open }\end{array}$ & $\begin{array}{l}\text { Licensing } \\
\text { Nata } \\
\text { Policy }\end{array}$ & $\begin{array}{l}\text { Norms } \\
\text { Extent of } \\
\text { coordinati } \\
\text { on at } \\
\text { national } \\
\text { level }\end{array}$ & $\begin{array}{l}4 . \\
\text { Use of } \\
\text { Data }\end{array}$ & $\begin{array}{l}5 . \\
\text { Impact } \\
\text { of } \\
\text { Open } \\
\text { Data }\end{array}$ & $\begin{array}{l}\text { Usability } \\
\text { of the } \\
\text { Portal }\end{array}$ & $\begin{array}{l}\text { Reusability } \\
\text { of data }\end{array}$ & $\begin{array}{l}\text { Spread } \\
\text { of data } \\
\text { cross } \\
\text { domains }\end{array}$ \\
\hline
\end{tabular}

\section{Discussion and Results}

In 2017, the impact on increasing transparency and accountability is estimated to be high by 13 countries 26 of the EU28+; an increase of five countries compared to 2015. In spite of that, there are large discrepancies across countries that do have a portal. The results of individual countries can be seen in the table below.

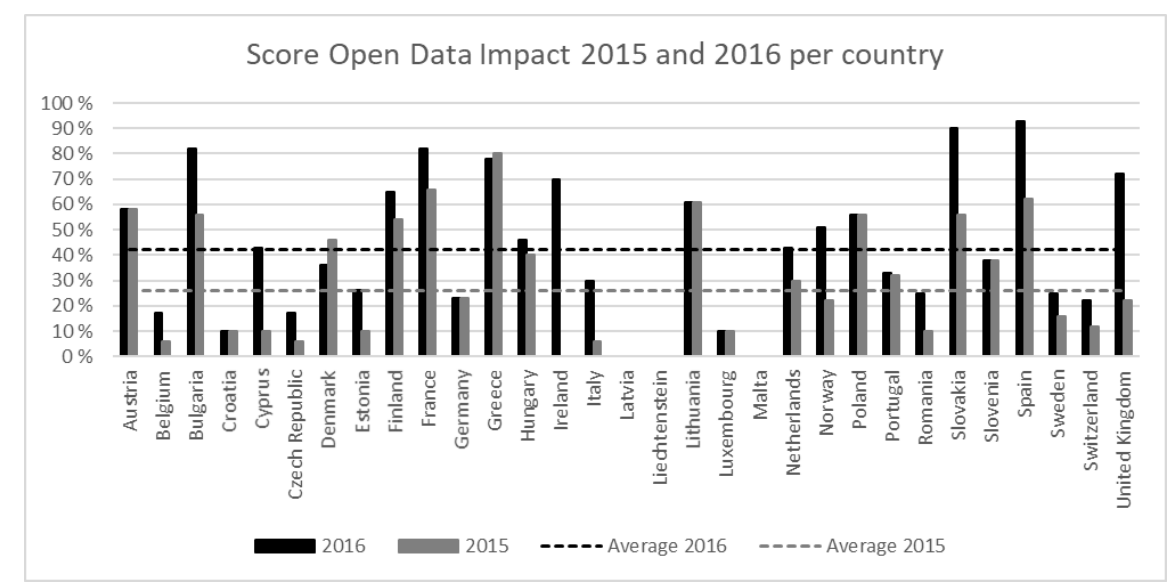

Fig. 1. Score Open Data Impact per country in 2015 and 2016, with averages 2015 and 2016. [7]

Figure 1 above represents the overall scores for individual countries and to the same extent provides the EU average scores for 2015 and 2016. Overall, the average score amongst EU28+ countries shows an increase from 72 points in 2015 to 128 points in 2016. Most countries have increased as they have launched activities to promote their Open Data policies and portals, as well as developing additional means to monitor their users. Among the most progressive countries on this indicator is Luxembourg. The launch of their national Open Data portal in the spring of 2016 can explain this increase. A few countries have a reduced score on Use of Open Data. 
This is partially down to the fact that, in 2016, the number of unique visitors was scored in relation to the number of inhabitants in a given country. However, this calculation adjustment has favoured smaller countries and not proven to be too much of a disadvantage for larger countries.

Open Data impact measurements are important because they provide a clear overview of where countries planned to reap - or are reaping - the benefits from their Open Data policy. By measuring this impact on an annual basis, it's possible to find out which countries are deepening their understanding of the Open Data impact.

Some effects of releasing Open Data are visible, but an estimation of the impact created by releasing data remains a challenge to precisely identify. The main recorded impacts have been grouped into three categories: political, social and economic. The 2015 scores were used as a baseline and updated based on data collected in 2016. This approach was chosen because the impact isn't necessarily measured by default on a yearly basis.

From the above-mentioned international results comparison, it's clear that digital transparency is an important part of the evaluation of public administration performance and they work together as combined vessels and confirm the Q1 research question.

\section{$5 \quad$ Conclusion and recommendations}

\section{Meaning of performance measurement by public administration as a benefit}

Performance information can be used to describe the current state of public administration functioning and its individual components, which is very valuable information, but very often also stimulating reflections and attempts to improve the state of functioning. This can clearly be seen as an advantage. Behn [2] also counts with this in his categorisation and defines eight possible uses of measured data and information obtained, especially within the management processes in the PA. It's the improvement which is an eighth way to use performance information that understands it as a goal superior to all other goals. These goals include:

1. Evaluate - How well is my public agency performing?

2. Control - How can I make sure that my subordinates are doing the right thing?

3. Budget - On what programmes, people or projects should my agency spend public money?

4. Motivate - How can I motivate my line staff, middle management, nonprofit and for-profit associates, stakeholders and citizens to do the necessary things to improve performance?

5. Promote - How can I convince political superiors, stakeholders, legislators, journalists and also citizens that my agency does a good job?

6. Celebrate - What achievements are worthy of the important organisational ritual of celebrating success? 
7. Learn - Why is something working or not?

8. Improve - Who should do exactly should what differently to improve performance?

For example, the EFQM Excellence Model, the Balance Scorecard, ISO standards, benchmarking, as well as newly developed methods can be used directly for public authorities as a CAF model, local Agenda 21 or tools engaging citizenship in the management, such as a citizens' charters or community planning.

To upturn performance, public managers are required to understand how they can influence the behaviour of the people inside their agency (and its associates), who produce their outputs and also how they can influence the citizens' behaviour, who convert these outputs into outcomes. They have to know what is going on inside their organisation - this includes the broader organisation that consists of everything and everyone whose behaviour can have an affect these outputs and outcomes. They have to know what is going on inside their entire, operational black box. [2]

Administrative difficulty, non-compliance with methodology or misinterpretation of results can be considered as restrictions.

Acknowledgements. The paper was written with the support of the specific project 6/2017 grant "Determinants affecting job satisfaction" granted by the University of Hradec Králové, Czech Republic and thanks to help of student Šárka Jelínková.

\section{References}

1. Alcaide Muñoz, L., Rodríguez Bolívar, M. P., \& López Hernández, A. M.: Transparency in Governments: A Meta-Analytic Review of Incentives for Digital Versus Hard-Copy Public Financial Disclosures. The American Review of Public Administration, 47(5), 550573. (2017). https://doi.org/10.1177/0275074016629008

2. Behn, R. D.: Why Measure Performance? Different Purposes Require Different Measures. Public Administration Review, 63(5), 586-606. (2003). https://doi.org/10.1111/15406210.00322

3. Birkinshaw, P.: Freedom of information: the law, the practice, and the ideal (4th ed). Cambridge ; New York: Cambridge University Press. (2010).

4. Bourgon, J.: A New Synthesis of Public Administration: Serving in the 21st Century. Canada: McGill-Queen's University Press. (2011).

5. Bowles, N., Hamilton, J., \& Levy, D. A. L. (Eds.). (2014). Transparency in politics and the media: accountability and open government. London; New York: I. B. Tauris \& Co. Ltd., in association with the Reuters Institute for the Study of Journalism, University of Oxford.

6. Christensen, L. T., \& Cornelissen, J.: . Organizational transparency as myth and metaphor. European Journal of Social Theory, 18(2), 132-149. (2015). https://doi.org/10.1177/1368431014555256

7. European Data Portal. Open Data Maturity in Europe 2016. European Commission. (2017). Retrieved from https://www.europeandataportal.eu/sites/default/files/edp_landscaping_insight_report_n2_ 2016.pdf

8. Hendrych, D.: Správní věda: teorie veřejné správy. Praha: Wolters Kluwer. (2014). 
9. Jara Iñiguez, I.: Comparative Analysis of Public Policies and Best Practices of Transparency in Ecuador 2004-2014, 67, 197-226. (2017).

10. Mohelska, H., Sokolova, M. Digital transparency in public sector - case study in Czech Republic. Economics and Management, 2017 (4), 203-209. https://doi.org/10.15240/tul/001/2017-4-016

11. MVČR. Strategický rámec rozvoje veřejné správy České republiky pro období 2014 2020. Ministerstvé vnitra ČR. (2016). Retrieved from http://www.mvcr.cz/clanek/strategicky-ramec-rozvoje.aspx

12. OECD. Public Governance and Territorial Development Public Management Committee. Building on Basics: OECD Value for Money Study, Final Report (hand-out). (2011). Retrieved from http://www.oecd.org/gov/budgeting/49042446.pdf

13. Oliver, R. W.: What is transparency? New York: McGraw-Hill. (2004). Retrieved from http://site.ebrary.com/id/10083650

14. Piotrowski, S. J., Van Ryzin, G. G.: Citizen Attitudes Toward Transparency in Local Government. The American Review of Public Administration, 37(3), 306-323. (2007). https://doi.org/10.1177/0275074006296777

15. Prat, A.: . The More Closely We Are Watched, the Better We Behave? In C. Hood \& D. Heald (Eds.), Transparency: The Key to Better Governance? (pp. 91-103). British Academy. (2006). https://doi.org/10.5871/bacad/9780197263839.003.0006

16. Sedon, J.: Systems Thinking in the Public Sector: The failure of the reform regime... and a manifesto for a better way. Station Yard. (2008). 